\title{
Human Rights, Health, Gender and Sexuality
}

\author{
Sri. Keshabanada Borah \\ Research Scholar,Gauhati University,Assam,India \\ Deptt of Political Science.
}

\section{Introduction}

The role of women in the development of a nation is very important now a day. In the world half of the populations are women. Women the mother of mankind pivot around the family, society and humanity itself evolves. It is said that if a man is educated one person is educated but if a women is educated, the whole family gets educated. Therefore for the survivability of the mankind and the world, the protection of the rights of the women is utmost concern. But in today's world where exploration of science and technology makes every thing possible, women occupy a secondary position in every field of the society. Here a little attempt has been made to examine the gender based discrimination among women and to provide some remedial measures so that women's right could be protected.

The three specific issues human rights, gender and sexuality are interlinked with each other. Discrimination on the basis of gender have the adverse effect upon dignity of human values/rights, health and sexuality. An individual's gender and sexuality determines the extent to which he or she is vulnerable. This gender inequality also hampers upon free access to economic resources, opportunities, political power and health services.

As universal phenomenon human rights provides guarantees and exaltation of dignity and human personality. The mere commonalities between human rights and public health is that both aims at promoting the wellbeing of all individuals. So far as gender is concerned, it is wrong to believe that gender is biologically determined. Gender determines the role that men and women play in society with relation to each other. It is a set of relations or norms as expected by male or society from female.

Where gender is societal concept, sexuality is biological. An individual's sexuality is defined by whom one has to sex with, in what ways and under what circumstances. Every society imposes certain formal and informal rules for an individual's sexuality.

Gender is the cornerstone which maintains a balance among human rights, health and sexuality. But gender in itself is a much contested term because the role of gender is not autonomous or free. In general, gender role is always predetermined. Ideology plays an important role in determining the role of gender. Ideology here is nothing but beliefs and values of a society. In another words, gender relations is institutional. Because it is the institutions or society which determines what role gender will play and when. Though gender inequalities exist among the rich and poor, but it tends to be greater among the poor especially in case of opportunities. Gender inequality restricts women's access to economic resources comprising their sexual and reproductive autonomy.

\section{Gender, Sexuality And Health}

In case of sexuality, women are more vulnerable than men to sexually transmitted infections, particularly HIV/AIDS. Today almost 50 percent of the HIV infected adults worldwide are women. Maternal mortality rates in pregnancy related cases in developing countries 50 times greater than in developed countries. Regarding women health consequences violence plays a very crucial role. It is estimated that violence against women causes death and incapacity among reproductive age women. Physical and sexual abuse lies behind unwanted pregnancies, sexually transmitted infections including HIV/AIDS and complication of pregnancy. Research studies show that one woman out of four is physically or sexually abuse during pregnancy period.

As a human being women have right to highest attainable standard of physical and mental health without any discrimination. Enjoyment of the human right to health is vital in all aspects of a person's life and wellbeing and crucial to the realization of many other fundamental human rights and freedom. UDHR mentions that (1) everyone has the right to standard of living adequate or health and wellbeing of himself and of his family. (2) Motherhood and childhood are entitled to special care and assistance. Cairo programme of action said," Everyone has the right to enjoyment of highest attainable standard of physical and mental health. State should take all appropriate measures to ensure on a basis of equality of men and women, universal access to health care service including those related to reproductive health care." 


\section{Gender Based Violence And Society}

Violence against women transcends across national and international boundary. It is already mentioned that women living in poverty are more vulnerable in gender based violence particularly adolescent girls. In day to day activities these women often feel insecurity-walking or talking in public place, collecting water or firewood when these activities are undertaken early in the morning or at late night. It is difficult to find out accurate statistical data on the prevalence of gender based violence. More than one factors relating to this issue. It may be due to the underreporting by victims and under recording by police. A research studies shows that at least 3 out of every 5 women in India face domestic violence. But reporting of such cases is extremely low. One of the notable factors for increasing gender based violence in India is the "culture of silence". Women maintains silence with feelings of shame, confusion, anguish, fear of defame their reputation or of reprisals.

Human right violations are committed against both men and women but its impact is differing depending on the sex. It means that such violence is directly related to the unequal distribution of power and the asymmetrical relationships that exist between men and women in our society. There is no single watertight compartment regarding the forms of gender based violence. Gender based violence can take many forms depending on the type of relationship and the type of power being exerted. This violence may form in to the following categories-rape and incest, sexual harassment at work place, trafficking in women, domestic violence and so on.

One can't examine domestic violence without proper understanding of the society. The socio-cultural factors act as a fuel in breeding domestic violence. The biased division of labour, discriminatory social order, stereotypical ideological and cultural attitudes passing through the socialization process frames a separate identity of women from men. Though poverty, alcoholism, unemployment are not considered to be direct causes of violence, but their contribution to spreading domestic violence cases can't be ignored.

Moreover, in traditional Indian societies women occupies a secondary position. Women's role is limited which in another way termed as "reproductive activities". Women even can't take part in decision making process except in few inevitable matters. Such circumstances compel the women to see domestic violence as a private matter, don't want interfered by others. There is also a diverse opinion on what constitutes domestic violence. Majority of women does not take into account sexual and psychological violence as domestic violence. It thus becomes forms what constitutes violence against women.

Though gender based violence always pointing out the finger to the male or 'masculinity' but it is the society which is the main culprit. The social apparatuses determine what to do or not to do by women. They are no freer to act according to their wish due to the restrictive social rules and norms allotted to women. The irony is that these rules create the sketch of an 'ideal girl' or an 'ideal women', but in another way it again restricts the rights and privileges that women have.

Gender based violence is increasing day by day but there is very little societal support for women. Though some civil society organizations and women's group stands by distressed women, but there is an absence of collective action. Justice is denied to abuse women due to the loopholes in the existing laws. Corruption also proves to be a major impediment in the path of justice. Yet some NGOs are engaging in disseminating legal knowledge to women.Rearch also shows that though a few women manage to gather the courage to approach the legal institutions i.e. police and judiciary but very often they have face gender sensitive norms from these institutions.

\section{Gender Discrimination In Practice}

As gender discrimination refers to the practices whereby one sex is given preferential treatment over others. Some forms of discrimination which are continue to exist in Indian social system are-

\section{(a) Discrimination in Socialization}

In our socialization process male children are preferred to social children. Discrimination between male and female children is made in matters relating to food, dress, health, education, domestic work etc.

\section{(b)Discrimination in distribution of power and work}

Discrimination also happens in distribution of power and work. Domestic works such as- cooking, looking after the children, washing clothes, keeping house neat and clean, looking after the domesticated animals, serving family members like a nurse on all days etc are branded as "women's work". Very rarely men do this work.

\section{(b) Women's health is ignored}

Women suffer from some distinctive health problems where men are free. Women have to undergo the distinctive biological process of pregnancy, delivering, nursing, feeding, child caring or rearing etc. Therefore women face problems like bodily weakness, high bleeding, fatness etc. 


\section{(c) Gender discrimination in occupation and public life}

Women workers are paid less than the male workers for the same type of work. In matters of giving treatment, promotion, increment, facilities etc discrimination is normally made.

\section{(d) Dowry leads to the degradation of women}

Prevalence of the practice of dowry reflects the inferior status of women. Some unscrupulous and money minded young men contact more than one marriage just for money. Moreover dowry harassment is many. Women are ill-treated, disrespected, tortured and subject to all sorts of cruelties in the name of dowry.

\section{Defining Gender From International Relations (Ir) Theoritical Perspective-}

IR feminist tries to examine why women are disadvantaged relative to men in all spheres. In putting this question IR Feminist defines gender as a set of socially constructed characteristics that define what we mean by masculinity and femininity. Gender is a system of social hierarchy in which masculine characteristics are more valued than feminine ones. Gender is a structure that signifies unequal power relationships between women and men.

Some feminists questions as of 2008, less than 9 per cent of the world's head of the state were women and most of the world's military personnel were men. Then "where are the women?" To answer these questions, IR feminists use a number of different theoretical approaches. Let us look at these approaches-

\section{(a) Liberal feminism}

Liberal feminist believe that women's equality can be achieved by removing legal obstacles that deny women the same opportunities as men.

\section{(b)Post-liberal feminism}

Post-liberal feminists argue that we must look more deeply at unequal gendered structures in order to understand women's subordination.

\section{(c)Feminist critical theory}

Feminist critical theorists show how both ideas and material structures shape people's lives and how changes in the meaning of gender have changed the practice of international organizations over time.

\section{(d) Post-structural feminism}

Post-structural feminists claim that there is a link between knowledge and power. Since men have generally been seen as knowers and as subjects of knowledge which influences global politics.

\section{(e) Postcolonial feminist}

Postcolonial feminists suggest that women's subordination must be differentially understood in terms of race, class and geographical location.

\section{(f) Marxist and socialist}

Marxist and socialist feminist note how women in the contemporary labour market are mostly in low paid, low status jobs. They argue that only to equal treatment of women is an overthrow of capitalist system.

IR Feminist theorists therefore hold that various factors determine for why women are legging behind in international forum. Other studies suggests that economic development policies of 'Structural adjustment programme' adopted by the IMF and the world Bank changes in international division of labour contribute to an increased "feminization of poverty" . IR Feminist theorist also argues war is a gendered activity; it is not reserved for women but to men.

\section{Global Gender Inequality ( $\%$ of Women)}

1. Head of the states and cabinet ministers-5\%

2. Work Hours $65 \%$

3. Total Income $10 \%$

4. Illerates $65 \%$

5. Refugees $80 \%$ (sources from Peterson and Runyan)

\section{A Slogan for Gender friendly Society}

No single intervention can eliminate gender based violence from the society. There is need the efforts of multipronge mechanism to confront the challenge so that a gender friendly society can be established. First of all a common platform should be established to address the gender based violence. The social organization 
should come out in making awareness and develops a sense of confidence building among women. The responsibility also lies with the civil society organizations and state agencies. Women movement should be organized to mobilize the diverse community group and serves as a pressure group to advocates the rights of women at national and international level.

The following measures can also be used to overcome the menace-

1. Firstly, people have to change their mindset. The social rules and norms which directly related to the gender based violence are not formed automatically. These are the handmade of people in the society. Until or unless these gender based discriminatory norms are abrogated women can't get free access in social, cultural, political and economic life.

2. A women rights based approach should be incorporated in the political process.

3. Education can play a key role in bringing awareness about impact of violence perpetrated against women. Female education should be promoted.

4. Budgetary allocation is potential to strengthening the rights of women.

5. There is need to establish state commission in each state.

6. There is need social responsibility especially male responsibility to mitigate violence against women.

7. Religious leaders and religious organizations can play a pivotal role to mould public opinion in ameliorating the condition of women.

\section{Books and articles-}

\section{References-}

[1] "The Globalization of world politics", edited by Baylis John, Smith Steve, Oxford university press, 2011.

[2] "Introduction to International Relation Theories and approaches" By Jackson Robert, Sorenson George, Oxford university press,2003

[3] "Sociology with an introduction to social thought" by Shankar Rao, S.Chand \& company limited 2006.

[4] "Human Rights, concepts and issues", Rehman Kanta, Commonwealth publication, Delhi 2003.

[5] “Indian Journal Of political science, 'Gender discrimination women's work and autonomy', Sangapa jyoti, Kaule Laxman.

[6] 'Gender equality Taking Action: Achieving Gender Equality and Empowering Women' achieving millennium development goal.'

[7] Violence against women in NE India: An Enquiry Report by- The Northeast Network, 2004, National commission for women, Delhi. 